\title{
Farmland management and sustainable development in the Mediterranean: land use changes, public policies, and collective resources
}

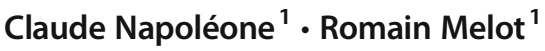 \\ Received: 5 January 2021 / Accepted: 7 January 2021 / Published online: 17 March 2021 \\ (C) The Author(s), under exclusive licence to Springer-Verlag GmbH, DE part of Springer Nature 2021
}

Mediterranean agricultural and natural areas are subject to intense ongoing anthropogenic and climatic pressures. Over time, the particularities of land tenure patterns (highly fragmented farming) and the strong urban influence on farmland markets on the coastal fringes are undermining the agricultural uses of land (Debolini et al., 2018; Soulard et al., 2017). Governance mechanisms at the local and national level have to consider competing interests in agricultural areas and political choices concerning the allocation of rights have a direct impact on the organization of land systems (Perrin et al., 2018).

Suburban and rural areas in northern and southern countries of the Mediterranean basin face similar challenges. Coastal areas are all experiencing unchecked urban sprawl, while the isolated hinterland has long been experiencing a steady agricultural decline, with large-scale abandonment of agriculture (Marraccini et al., 2015). Common farmland and grazing systems are confronted with private appropriation and land management problems, climate change impacts, and reduced resource availability (Akasbi et al., 2012). At the same time, important social and political changes are underway in rural territories. Local communities are pressurizing public authorities for access to land, while acquisition by private investors and land grabbing raise major concerns among rural populations. Inclusive land allocation processes and the struggle against social segregation in agricultural spaces are at the heart of national and local land policy agendas.

This article is part of the Topical Collection on Farmland Management

Claude Napoléone

claude.napoleone@inrae.fr

Romain Melot

romain.melot@inrae.fr

1 INRAE, Paris, France
The aim of this Topical Collection is to analyze the constraints and opportunities for careful use of land resources and for sustainable patterns of agricultural development, in the context of Mediterranean land systems. This Collection is based on an international conference in Thessaloniki in 2017, organized by the FonciMed network. For the past decade, FonciMed has been bringing together researchers of various academic fields from both sides of the Mediterranean to discuss farmland management issues. The articles selected from the conference deal primarily with two dimensions of land management: (1) regulation of farmland by public policies for territorial development and (2) collective resources as a development lever for a sustainable management of farmland.

Farmland in Mediterranean areas is subject to heavy pressure for conversion to residential and touristic uses (Ceccarelli et al., 2014). Studies on local agricultural markets show that landowners and private investors in suburban areas anticipate land conversions, thus causing intense speculation in many agricultural areas on the coast. At the same time, agricultural activities are also jeopardized by the risk of land abandonment resulting from the rural exodus in remote areas of the hinterland, although in suburban areas it may also be connected to the pressure for artificialization.

Public policies employ various tools to address the challenge of farmland preservation. Planning authorities have to deal with the allocation of building rights and the management of urban sprawl, which involves trade-offs between different interests (Tassinari et al., 2013; Marques-Perez and Segura, 2018). At the national or local level, tax policies may drive the behaviors of farmers (as landowners or tenants) to preserve declining agricultural activities. Many Mediterranean areas are moreover also concerned by conservation policies that imply negotiation with local actors (farmers, residents, etc.) over the sustainable use of farmland.

The inquiry conducted by Akimowicz et al. (2020) in the South of France (Toulouse region) examines the diverging 
rationales underpinning the local policy agenda. It suggests several avenues of improvement concerning the combination of various policy tools to address the issue of farmland preservation. The study exemplifies these issues of farmland protection in suburban areas with a focus on the challenge of collective action. It investigates the social and institutional conditions that may consolidate coordination between actors of the agricultural sector, with a view to advocating for the interests of farmland preservation. Based on a sample of interviews with farmers, agricultural unions, and farm advisors, the authors explore the output of negotiations with planning authorities through the analysis of multi-stakeholder coalitions.

On both shores of the Mediterranean, collective forms of land management have proved to be resilient, especially in the case of extensive agropastoral systems (Oteros-Rozas et al., 2013; Sidiropoulou et al., 2015). Yet political reforms are tending to reduce the scope of the commons and to promote an agricultural development based on private appropriation. These divergent trends may sometimes lead to an overlap of land management systems at the local level. Research on rural development has long highlighted the fact that collective land management is likely to favor a diversification of land uses and help to reduce anthropic pressure on natural environments. When natural resources are scarce (soil erosion, lack of grazing, and water shortage), a community-based management of pastureland and cultivation practices may be a lever for a sustainable development of farming systems.

The management of collective resources includes not only common lands but also common goods that may be developed by a social community. This applies in particular to enhancement by extensive agricultural or livestock activities. Ragkos et al. (2020) study the case of transhumance practices on grazing land in northern Greece as a multi-functional production system that constitutes a common good and social system (particularity of the Greek transhumance organization which involves the whole family of breeders). The authors examine the issue of social access to pastures; they compare the form of different local organizations and characterize how these systems manage various uses between breeders. Through local surveys with a sample of breeders, they highlight the cultural and economic role of transhumance (local solidarity, impact on production quality), as well as its ecological function (ecosystemic services produced).

Dealing also with collective management of farming activities in Balkan mountainous territories, another article is based on inquiries in the rural regions of Albania. Bernard-Mongin et al. (2021) consider the specific case of aromatic plant picking in Albania. Based on archives and interviews with plant collectors, the study examines the resilience of a communitybased collection system on common mountainous pastures and forest land, after successive periods of centralized organization (through state cooperatives during the socialist regime) and deregulated markets (after the regime collapsed). In a context where plant picking plays an important economic role (high added value) for local communities, the article sheds light on the innovative collective actions that are implemented locally to manage these commons through sustainable rules.

Mediterranean areas are characterized by heavy pressure on land resources due to both the intensity and the variety of economic uses: increasing urban sprawl concentrated on the limited fringes of coastal areas, the important role played by tourist activities, and highly labor-intensive agricultural valorization. The articles of this Topical Collection adopt different angles and document current controversies on agricultural spaces by reconsidering the role of land tenure in rural development processes: barriers to social inclusion, new urbanrural partnerships, and the resilience of collective action. The contribution of this Topical Collection is to propose a longterm and multi-disciplinary perspective on agricultural activities in the Mediterranean context, by updating the analysis of the various socio-economic dimensions of farmland management that are coming to light.

\section{References}

Akasbi Z, Oldeland J, Dengler J, Finckh M (2012) Social and ecological constraints on decision making by transhumant pastoralists: a case study from the Moroccan Atlas Mountains. In J Mt Sci 9(3):307321. https://doi.org/10.1007/s11629-009-2320-8

Akimowicz M, Képhaliacos C, Landman K, Cummings H (2020) Planning for the future? The emergence of shared visions for agriculture in the urban-influenced Ontario's Greenbelt, Canada, and Toulouse InterSCoT. France. Reg Environ Chang 20:57. https:// doi.org/10.1007/s10113-020-01635-4

Bernard-Mongin C, Hoxha V, Lerin F (2021) From total state to anarchic market: management of medicinal and aromatic plants in Albania. Reg Environ Chang 21:5. https://doi.org/10.1007/s10113-02001727-1

Ceccarelli T, Bajocco S, Perini L, Salvati L (2014) Urbanisation and land take of high quality agricultural soils - exploring long-term land use changes and land capability in northern Italy. Int J Environ Res 8: 181-192. https://doi.org/10.22059/ijer.2014.707

Debolini M, Marraccini E, Dubeuf JP, Geijzendorffer IR, Guerra C, Simon M, Targetti S, Napoléone C (2018) Land and farming system dynamics and their drivers in the Mediterranean Basin. Land Use Policy 75:702-710. https://doi.org/10.1016/j.landusepol.2017.07. 010

Marraccini E, Debolini M, Moulery M, Abrantes P, Bouchier A, Chéry JP, Sanz Sanz E, Sabbatini T, Napoleone C (2015) Common features and different trajectories of land cover changes in six western Mediterranean urban regions. Appl Geogr 62:347-356. https://doi. org/10.1016/j.apgeog.2015.05.004

Marques-Perez I, Segura B (2018) Integrating social preferences analysis for multifunctional peri-urban farming in planning. An application by multi-criteria analysis techniques and stakeholders. Agroecol Sustain Food Syst 42:1029-1057. https://doi.org/10.1080/ 21683565.2018.1468379

Oteros-Rozas E, Ontillera-Sánchez R, Sanosa P, Gómez-Baggethun E, Reyes-García V, González J (2013) Traditional ecological knowledge among transhumant pastoralists in Mediterranean Spain. Ecol Soc 18(3):33. https://doi.org/10.5751/es-05597-180333 
Perrin C, Nougarèdes B, Sini L, Branduini P, Salvati L (2018) Governance changes in peri-urban farmland protection following decentralisation: a comparison between Montpellier (France) and Rome (Italy). Land Use Policy 70:535-546. https://doi.org/10. 1016/j.landusepol.2017.09.027

Ragkos A, Koutsou S, Karatassiou M, Parissi ZM (2020) Scenarios of optimal organization of sheep and goat transhumance. Reg Environ Chang 20:13. https://doi.org/10.1007/s10113-020-01598-6

Sidiropoulou A, Karatassiou M, Galidaki G, Sklavou P (2015) Landscape pattern changes in response to transhumance abandonment on Mountain Vermio (North Greece). Sustainability 7:15652-15673. https://doi.org/10.3390/su71115652
Soulard CT, Valette E, Perrin C, Abrantes PC, Anthopoulou T et al (2017) Peri-urban agro-ecosystems in the Mediterranean: diversity, dynamics, and drivers. Reg Environ Chang 2017(18):1-12. https:// doi.org/10.1007/s10113-017-1102-z

Tassinari P, Torreggiani D, Benni S (2013) Dealing with agriculture, environment and landscape in spatial planning: a discussion about the Italian case study. Land Use Policy 30:739-747. https://doi.org/ 10.1016/j.landusepol.2012.05.014

Publisher's note Springer Nature remains neutral with regard to jurisdictional claims in published maps and institutional affiliations. 